\title{
A Closer Look (Mini Case Studies)
}

\section{Chapter 1}

DC Central Kitchen 6

\section{Chapter 2}

The Harvard Cooperative Society 42

The Avalon Theatre 52

Newman's Own 54

Endless Sky 56

Rivanna Natural Designs 58

\section{Chapter 3}

The Massachusetts Association of Community Development Corporations 72

Partners for the Common Good 74

The Georgetown Business Improvement District 75

Workforce Development in the District of Columbia 78

Choral Expression in Washington, DC 83

National Rural Electrical Cooperative (NREC) 85

ROC USA, Resident-Owned Communities 89

\section{Chapter 4}

Community Health \& Social Service Center in Detroit 104

NeighborWorks America 109

DC Rape Crisis Center 112 
xviii A Closer Look (Mini Case Studies)

\section{Chapter 5}

American Federation of Labor/Congress of Industrial Organizations (AFL-CIO) 132

Better Business Bureau 136

Alcoholics Anonymous 143

Wikipedia 149

\section{Chapter 6}

United Way of America 162

www.Kiva.org (Kiva) 168

Girls Inc. 169

BoardSource 174

Recreational Equipment, Inc. (REI) 182

\section{Chapter 7}

Nancy Brinker, CEO, Susan G. Komen for the Cure (Komen) 192

Dr Govindappa Venkataswamy (Dr V) of the Aravind Hospital 198

Cleveland Clinic 200

The Oakland Symphony 207

Roca (Rock in Spanish) 209

Good Shepherd Services 213

\section{Chapter 8}

The United Nations Global Compact 226

Pets on Wheels of Scottsdale 234

Arizmendi Association of Cooperatives 237

Cabot Creamery Cooperative 239

marketumbrella.org 242

\section{Chapter 9}

Tucson Botanical Gardens 255

W.K. Kellogg Foundation 264

United Parcel Service, Inc. (UPS) 270

CROPP Cooperative 275

The Nonprofit Finance Fund (a CDFI) 277

\section{Chapter 10}

Assigning Proxy Values 292

Social Return on Investment Principles 303

The Fulbright Academy for Science \& Technology 306

Organically Grown Company 308 